Volume V, No.1 Juni 2015/1436 H

\title{
PENGARUH PEMAKAI DAN KONFLIK PEMAKAI TERHADAP KUALITAS SISTEM INFORMASI AKUNTANSI DENGAN LIMA VARIABEL MODERATING DI SKPD PEKANBARU
}

\author{
Kusumaningdiah Retno Setiorini
}

Universitas Islam Indonesia

Email: rini.suharsono@yahoo.com

\begin{abstract}
The purpose of this study was to test the influence of users and user conflict on the quality of accounting information systems with superior support, user communications developer, the complexity of the task, the complexity of the system, the user experience as a variable moderating. The method used survey method with processed primary data obtained from the questionnaire. The population in this study was 98 SKPD Pekanbaru which has a function as a task of financial matters relating to the quality of accounting information systems with the number of samples that can be analyzed as much data as 78 respondents. The sampling technique used purposive sampling. Test data validation and reliability of respondent data using Pearson product moment and Cronbach's alpha. Data were analyzed using Moderated Regression Analysis (MRA).

The results showed (1) Effect of users positive effect on the quality of accounting information systems. (2) Conflict users will not negatively affect the quality of accounting information system. (3) The influence of supervisor support moderated wearer no positive effect on the quality of accounting information systems. (4) The effect of the user moderated user communications developer is not a positive influence on the quality of accounting information systems. (5) Effect of users moderated complexity of the task is not a positive influence on the quality of accounting information systems. (6) The effect of the user moderated system complexity is not a positive influence on the quality of accounting information systems. (7) Effect of the wearer moderated user experience no positive effect on the quality of accounting information systems. (8) Conflict wearer superior failed to support moderated negative effect on the quality of accounting information systems. (9) Conflict wearer user communication moderated the developer is not a negative effect on the quality of accounting information systems. (10) The conflict wearer moderated complexity of the task is not a negative effect on the quality of accounting information systems. (11) Conflicts user moderated system complexity is not a negative effect on the quality of accounting information systems. (12) Conflicts wearer moderated user experience a negative effect on the quality of accounting information system.
\end{abstract}

JESI

JURNAL EKONOMI

SYARIAH

INDONESIA
Keywords: influence of users, user conflict, supervisor support, user communications developer, the complexity of the task, the complexity of the system, the user experience. 


\section{PENDAHULUAN}

Kualitas sistem informasi akuntansi yang baik dapat dilaksanakan dan dapat dinilai berjalan secara efektif dikarenakan dapat memenuhi kebutuhan dan keinginan berbagai konstituen yang ada dalam organisasi, baik secara individual maupun secara kelompok. Menurut Romney (2010:3) sistem informasi akuntansi memiliki komponen sebagai berikut: dapat dipercaya dengan berbasis komputer (computer based system). Menurut Nugroho (2011: 56) tujuan dari penyusunan sistem informasi akuntansi memiliki beberapa tujuan yang dapat disimpulkan sebagai berikut: (1) Untuk memberikan informasi akuntansi yang cepat, (2) Untuk menghasilkan informasi akuntansi yang efisien, (3) Untuk menghasilkan informasi akuntansi yang dapat dipercayai keandalannya, (4) Untuk memberikan informasi akuntansi yang berguna bagi perencanaan.

Menurut Bodnar dan Hopwood (2003) kualitas informasi merupakan tingkat dimana sebuah data yang telah diproses oleh sistem informasi menjadi memiliki arti bagi penggunanya, yang bisa berupa fakta dan suatu nilai yang bermanfaat. Dapat diperoleh kejelasan bahwa pentingnya kualitas sistem tidak dapat dinilai dari jumlah sumber daya yang dihabiskan untuk pengembangan sistem - sistem, namun diartikan sebagai suatu pengganti dasar untuk keberhasilan sebuah sistem. Sehingga menjadi pertanyaan menarik, bagaimana suatu sistem informasi akuntansi dinilai berkualitas?. Hal tersebut tergantung terhadap banyak faktor antara lain faktor internal dan factor eksternal, factor internal termasuk didalamnya personalia maupun pengembang dari sistem informasi itu sendiri. Faktor eksternal termasuk didalamnya para user (warga masyarakat, stake holder), peningkatan kinerja secara keseluruhan baik menyangkut karyawan, pimpinan.

Dengan kata lain pemakai memandang dari sudut ketersediaan layanan informasi, daripada menilai langsung kemampuan fungsi dari suatu system. Dalam Tjhai Fung Jen (2002) menunjukkan perbedaan penentuan keberhasilan komputer adalah tidak berdiri sendiri sehingga pemakai sistem digunakan untuk melakukan penelitian mengenai sistem informasi. Sehingga penggunaan dari sistem memiliki dampak atau pengaruh pemakai baik secara individu yang mana dampak dari individu secara kolektif akan berdampak pada organisasional (Menurut Choe.1996 dalam Acep Komara (2005). Penelitian tentang sistem informasi akuntansi telah banyak dilakukan, tetapi hasilnya masih belum konsisten. Sistem informasi akuntansi dapat diartikan sebagai susunan berbagai dokumen, alat komunikasi, tenaga pelaksana dan berbagai laporan yang didesain untuk mentransformasikan data keuangan menjadi informasi keuangan yang dibutuhkan manajemen (Widjajanto, 2001:4) dengan demikian (Nugroho, 2001) suatu sistem dinilai berjalan secara efektif, apabila mampu memenuhi kebutuhan dan keinginan berbagai pengguna yang ada dalam organisasi baik secara individual maupun secara kelompok. Informasi tersebut berkualitas apabila akurat, tepat waktu, lengkap dan ringkas. (Gibson et al 2003). Menurut Bodnar dan Hopwood (1995), berpendapat bahwa perubahan dari sistem manual ke sistem komputerisasi, tidak hanya menyangkut perubahan teknologi tetapi juga perubahan perilaku dan organisasional.

Dari beberapa hasil penelitian menggunakan pendekatan faktor kontinjensi dianggap berpengaruh secara sistematis mengevaluasi berbagai kondisi atau variabel-variabel yang dapat mempengaruhi hubungan antara

Musyafiq $\mathrm{H}$. Abdullah Salam

JURNAL EKONOMI SYARIAH INDONESIA, Volume V, No.1 Juni 2015 
pengaruh pemakai dan konflik pemakai dalam kualitas sistem informasi akuntansi, seperti penelitian atas tingkat pengaruh dari pemakai (Robey dan farrow, 1982), komunikasi (Debrabander dan Their 1984), dukungan manajemen puncak (Kim dan Lee, 1986), sikap pemakai (Thait dan Vessey, 1988), karekteristik organisasi (Thait dan Vessey, 1988), kompleksitas tugas (Mckeen et al., 1994). Oleh Handrianto, 2006, meneliti pengaruh dukungan manajemn puncak dan kompleksitas tugas terhadap sistem informasi akuntansi, hasilnya bahwa dukungan manajemen puncak tidak berpengaruh terhadap penerapan sistem informasi akuntansi. Oleh (Elfreda, 2003) meneliti menggunakan lima variable moderating, diantaranya moderating atas pengaruh pemakai dengan hasil yang positif signifikan atas system informasi akuntansi, sedangkan oleh (Sadat Amrul dan Ahyadi Syar'ie, 2005) meneliti dengan hasil bahwa pengaruh pemakai dan konflik pemakai memiliki hasil negative tidak signifikan. Hasil yang tidak jelas (equivocal), ini disebabkan terbatasnya teori dan tidak lengkapnya metodologi.

\section{METODE PENELITIAN}

\section{Desain Penelitian}

Pada penelitian ini metode yang digunakan adalah metode survey yang merupakan penelitian lapangan terhadap beberapa anggota sampel dari suatu populasi tertentu yang pengumpulannya dilakukan dengan menggunakan kuisioner (Sekaran, 2000). Jenis penelitian ini adalah kuantitatif, Kuantitatif menurut Sugiyono, 2012:7 dimaksudkan metode penelitian yang berdasar pada filsafat positivisme, digunakan untuk meneliti pada populasi atau sampel tertentu. Populasi dalam penelitian ini adalah pemerintahan Pekanbaru, yang memiliki 98 SKPD, meneliti secara individu, yaitu pegawai negeri sipil pada bagian akuntansi/penatausahaan keuangan. Dasar penentuannya adalah Central Limit Theorem (Mendenhall dan Beaver, 1981) yang menyatakan bahwa jumlah minimal sampel untuk mencapai kurva normal setidaknya adalah dengan mencapai nilai responden minimum 30 sampel.

\section{Populasi Penelitian dan Sampel Penelitian}

Populasi penelitian adalah bagian akuntansi/ penatausahaan keuangan pada SKPD di Kota Pekanbarau. Unit analisis adalah individu, yaitu pegawai negeri sipil pada SKPD di Kota Pekanbaru. Sedang sampel penelitian dilakukan secara purposive sampling, dimana informasi yang akan diambil berasal dari sumber yang sengaja dipilih berdasar kriteria yang telah ditetapkan peneliti (Sekaran, 2003). Sehingga respon yang akan diuji berjumlah 98 orang pegawai negeri sipil disetiap SKPD di Kota Pekanbaru.

Menurut (Sekaran, 2003), purpose sampling digunakan karena informasi yang diambil berasal dari sumber yang sengaja dipilih berdasarkan kriteria tertentu yang telah ditetapkan peneliti. Kriteria penelitian ini adalah: a. Individu pegawai negeri sipil di seluruh SKPD Kota Pekanbaru, dan b. Melaksanakan fungsi atau bertugas akuntansi atau penatausahaan keuangan, sebagai staf bagian akuntansi atau penatausahaan keuangan, sebanyak 1

Pengaruh Pemakai orang yang menjadi responden dari 98 SKPD Pekanbaru. Penentuan kriteria berdasarkan atas alasan bahwa staf keuangan/akuntansi adalah pihak yang terlibat langsung secara teknis dalam pencatatan dan pelaporan keuangan pemerintah daerah. Distribusi sampel pada tiap SKPD meliputi Kantor, Dinas, dan Badan di lingkungan pemerintahan daerah kota Pekanbaru. 


\section{Definisi Operasional Variabel}

Definisi operasional adalah faktor - faktor yang digunakan dalam penelitian ini, terdiri dari tiga yaitu variabel independent, variabel dependent dan variabel pemoderasi.

\section{Variabel independen atau variable bebas $(X)$.}

Menurut Mudrajat (2003) variabel eksogen (independen) adalah variable yang dapat mempengaruhi perubahan dalam variabel terikat dan mempunyai pengaruh positif ataupun negative bagi variabel endogen (depend). Pengaruh pemakai dengan tingkat yang tinggi menjadi pembuat keputusan yang efektif dalam proses pengembangan sistem melalui latihan - latihan dan tanggung jawab (Guimaraes, Staples, dan McKeen, 2003). Konflik pemakai kondisi divergensi kepentingan, pendapat atau tujuan diantara menciptakan kualitas sistem informasi akuntansi diharapkan menghasilkan hasil negative selama pengembangan kualitas sistem informasi akuntansi.

\section{Variable depend atau variable terikat $(Y)$}

Variabel eksogen (depend) menurut mudrajat (2003) adalah variable yang menjadi perhatian utama dalam sebuah pengamatan. Penelitian ini variabel endogen (depend) adalah kualitas sistem informasi akuntansi. Kualitas diukur menggunakan 10 item yang diadaptasi dari Yoon, guimaraes, dan O'Neal (1995); Guimaraes, Yoon, dan Clevenson, (2001). Diukur dengan skala 5 likert yang mengindikasikan tingkat 1 (tidak ada sama sekali) sampai dengan 5 (sangat besar).

\section{Variabel Pemoderasi}

Pengaruh Pemakai

McKeen et al (1994) menunjukkan bahwa pengaruh pemakai bukan merupakan moderating variable, melainkan sebagai independent predictor. Berbeda dengan Nurika Restuning diah (1999) bahwa pengaruh pemakai berpengaruh sebagai quasi moderator dan pengukuran variabel ini merupakan adaptasi dari Franz Robey (1986) instrument ini dikembangkan dengan 12 item pertanyaan dan skala tinggi (6) menunjukkan sangat banyak, skala (1) tidak sama sekali dan dimuat oleh Elfreda (2004).

\section{Konflik Pemakai}

Konflik pemakai yang dimaksud adalah konflik anggota yang pernah terjadi dalam organisasi yang mungkin merusak komunikasi dalam mencapai kualiats sistem (Robey dan farrow, 1982; Robey et al., 1989; 1993). Konflik anggota timbul dari konflik pemakai yang diciptakan dari keadaan stres psikologi didalam lingkungan kerja (Kennis, 1979), dapat berupa reaksi emosional yang bersifat negative terhadap masalah masalah yang berhubungan dengan pekerjaan (Vossel dan Froeh.

\section{Dukungan Atasan}

Dukungan atasan memiliki perilaku eksekutif yang berhubungan dengan perencanaan sistem informasi, pengembangan dan implementasinya. Variabel ini diukur dengan instrumen Vanlomel dan DeBrabander (1975). Dukungan atasan dapat diukur dengan instrument yang dikembangkan oleh vanlommel

K. Retno

Setiorini

JURNAL EKONOMI SYARIAH INDONESIA, Volume V, No.1 Juni 2015 
dengan nilai cronbach alpha sebesar 0,82. Instrumen ini telah digunakan oleh Sunarti Setianingsih (1998) dan skala 5 likert dimana nilai (1) sangat rendah dan nilai (5) sangat tinggi dibangun dari Elfreda (2004).

Komunikasi Pemakai - Pengembang

Kemampuan pemakai dalam berkomunikasi, sehingga pemakai dan pengembang dapat berkomunikasi secara efektif. Pemakai mampu memberikan input kepada keputusan pengembangan system informasi (Monge dkk, 1983) dan telah dimodifikasi oleh Guinan (1988) dan pada tahun 1994 digunakan oleh McKeen dkk, terdiri dari item dengan menggunakan skala Likert untuk menilai kualitas komunikasi pemakai - pengembang, menunjukkan nilai alpha sebesar 0,54. Pada I Wayan (2007) komunikasi pemakai pengembang adalah kemampuan pemakai dalam berkomunikasi sehingga pemakai dan pengembang dapat berkomunikasi secara efektif, dan dibangun dalam Deni (2011).

\section{Kompleksitas Tugas}

Persepsi individu mengenai tingkat kesulitan suatu tugas dalam pengembangan sistem informasi. Dapat ditarik kesimpulan bahwa suatu tugas sulit bagi seseorang, namun belum tentu sulit bagi orang lain. Variabel ini diukur dengan instrumen Rizzo dkk (1970), dengan menggunakan skala Linkert. Instrumen ini digunakan oleh McKeen et al (1994) dengan nilai alpha sebesar 0,75 dan kuisioner ini dipakai dalam Grahita Chandarin dan Nur Indrianto (1997) dan Nurika Restuningdiah (1998) nilai alpha sebesar 0,99. Bahwa konsistensi internal data yang sangat memadai, melalui penggunaan instrument kompleksitas tugas yang menggunakan 6 item dengan skala 7 (sangat besar) dan 1 (sangat salah) dan dimuat dalam Elfreda (2004).

\section{Kompleksitas Sistem}

Kompleksitas sistem yang mengacu pada teknologi yang digunakan oleh suatu organisasi dengan anggapan bahwa kompleksitas adalah relatif terhadap setiap organisasi dan tidak mutlak. Variabel ini diukur dengan instrumen McFarlan (1982). Kompleksitas sistem diukur oleh Mcfarlan (1982), dengan 3 item dan rentang nilai yang digunakan adalah dari 1 sampai 7, dimana nilai 1 tidak jelas atau dan nilai 7 dengan spesifikasi jelas atau sangat sederhana. Instrumen ini digunakan oleh Mckeen (1994) dengan nilai alpha sebesar 0,89 dan instrument ini digunakan Nurika Restuningdiah (1999) dengan nilai alpha sebesar 0,65 menunjukkan bahwa data yang terkumpul melalui instrument ini reliable dan dimuat oleh Elfreda (2004).

Pengalaman Pemakai

Tingkat pengalaman dan ketrampilan yang diperoleh pemkai dalam hal penggunaan komputer dan pengembangannya (Guimaraes, dan davis yang diadopsi oleh Guimaraes, Staples, dan McKeen (2003), variable ini diukur dengan lima skala likert, dari nilai 1 tidak ada sama sekali, sampai dengan 5 sangat besar. Bagian ini menejelaskan definisi operasional variabel terdiri dari variabel, dimensi, indikator dan skala pengukurannya. Berikut table

Pengaruh yang menjelaskan definisi operasional variabel dimuat dalam Astusi (2013):

Pemakai Kualitas Sistem Informasi

Yoon, Guimaraes, dan O'neal (1995); Guimaraes, Yoon, dan Clevenson (2001) masing item diukur dengan skala linkert yang mengindikasikan skala 1 
(tidak sama sekali) sampai dengn 5 (sangat besar) yang dimuat dalam Amru, Sadat dan Ahyadi Syar"ie (2005):

\section{HASIL PENELITIAN DAN PEMBAHASAN}

\section{Coefficients $^{a}$}

\begin{tabular}{|c|c|c|c|c|c|c|}
\hline \multirow{2}{*}{\multicolumn{2}{|c|}{$\begin{array}{l}\text { Model } \\
\text { B }\end{array}$}} & \multicolumn{2}{|c|}{ Unstandardized Coefficients } & \multirow[t]{2}{*}{$\begin{array}{l}\text { Standardized } \\
\text { Coefficients }\end{array}$} & \multirow[t]{2}{*}{$\mathrm{t}$} & \multirow{2}{*}{ Sig. } \\
\hline & & Std. Error & Beta & & & \\
\hline \multirow{12}{*}{1} & (Constant) & -199.044 & 66.765 & & -2.981 & .004 \\
\hline & x1 & 3.704 & 1.188 & 3.970 & 3.118 & .003 \\
\hline & x3 & 2.097 & .523 & 2.358 & 4.006 & .000 \\
\hline & $x 4$ & -6.586 & 2.418 & -2.414 & -2.724 & .008 \\
\hline & x5 & 2.823 & 2.302 & 1.271 & 1.226 & .224 \\
\hline & $x 6$ & -3.141 & 2.437 & -.991 & -1.289 & .202 \\
\hline & x7 & 6.946 & 1.394 & 6.105 & 4.983 & .000 \\
\hline & $\mathrm{X} 1 \mathrm{X} 3$ & -.035 & .009 & -3.653 & -3.979 & .000 \\
\hline & $\mathrm{X} 1 \mathrm{X} 4$ & .136 & .042 & 4.085 & 3.213 & .002 \\
\hline & X1X5 & -.054 & .042 & -2.354 & -1.297 & .199 \\
\hline & X1X6 & .070 & .045 & 1.580 & 1.533 & .130 \\
\hline & X1X7 & -.123 & .025 & -7.637 & -4.986 & .000 \\
\hline
\end{tabular}

a. Dependent Variable: YY

Dengan persamaan regresi model penelitian I:

$\mathrm{KP}=\mathrm{a} 1+\beta 1 \mathrm{X} 1+\beta 3 \mathrm{X} 3+\beta 4 \mathrm{X} 4+\beta 5 \mathrm{X} 5+\beta 6 \mathrm{X} 6+\beta 7 \mathrm{X} 7+\beta 8 \mathrm{X} 1 \mathrm{X} 3+\beta 9$ $\mathrm{X} 1 \mathrm{X} 4+\beta 10 \mathrm{X} 1 \mathrm{X} 5+\beta 11 \mathrm{X} 1 \mathrm{X} 6+\beta 12 \mathrm{X} 1 \mathrm{X} 7+\mathrm{e}$

$\mathrm{KP}=-199,044+3,704 \mathrm{X} 1+2,097 \mathrm{X} 3-6,586 \mathrm{X} 4+2,823 \times 5-3,141 \mathrm{X} 6+6,946$ X7 - 0,035 X1X3 + 0,136 X1X4 - 0,054 X1X5 + 0,070 X1X6 - 0,123 X1X7 + e

\section{Coefficients $^{\mathrm{a}}$}

\begin{tabular}{|c|c|c|c|c|c|c|}
\hline & Model & $\begin{array}{l}\text { Unstand } \\
\text { Coeffic }\end{array}$ & $\begin{array}{l}\text { Irdized } \\
\text { ients }\end{array}$ & $\begin{array}{l}\text { Standardized } \\
\text { Coefficients }\end{array}$ & $\mathrm{t}$ & Sig. \\
\hline & & Std. Error & Beta & & & \\
\hline & (Constant) & -26.593 & 70.691 & & -.376 & .708 \\
\hline & x3 & .662 & 1.822 & .744 & .363 & .717 \\
\hline & $x 4$ & -3.533 & 2.518 & -1.295 & -1.403 & .165 \\
\hline & $x 5$ & .648 & 1.728 & 292 & .375 & .709 \\
\hline & $x 6$ & -3.137 & 2.734 & -.989 & -1.147 & .255 \\
\hline 1 & $\mathrm{x} 7$ & 3.983 & .916 & 3.500 & 4.347 & .000 \\
\hline & $\mathrm{x} 2$ & 1.895 & 5.205 & .433 & .364 & .717 \\
\hline & $\mathrm{X} 2 \mathrm{X} 3$ & -.044 & .122 & -.828 & -.359 & .720 \\
\hline & $\mathrm{X} 2 \mathrm{X} 4$ & .318 & .181 & 2.361 & 1.750 & .085 \\
\hline & $\times 2 \times 5$ & -.052 & .132 & -.551 & -.393 & .696 \\
\hline & $\times 2 \times 6$ & .318 & .214 & 1.994 & 1.490 & 141 \\
\hline & $\mathrm{X} 2 \mathrm{X} 7$ & -.285 & .067 & -4.781 & -4.287 & .000 \\
\hline
\end{tabular}

a. Dependent Variable: $Y Y$

K. Retno

Setiorini

98

JURNAL EKONOMI SYARIAH INDONESIA, Volume V, No.1 Juni 2015 
Dengan persamaan regresi model penelitian II:

$\mathrm{Kp}=\mathrm{\alpha} 2+\beta 2 \mathrm{X} 2+\beta 3 \mathrm{X} 3+\beta 4 \mathrm{X} 4+\beta 5 \mathrm{X} 5+\beta 6 \mathrm{X} 6+\beta 7 \mathrm{X} 7+\beta 8 \mathrm{X} 2 \mathrm{X} 3+\beta 9$ $\mathrm{X} 2 \mathrm{X} 4+\beta 10 \mathrm{X} 2 \mathrm{X} 5+\beta 11 \mathrm{X} 2 \mathrm{X} 6+\beta 12 \mathrm{X} 2 \mathrm{X} 7+\mathrm{e}$

$\mathrm{KP}=-26,93+1,893 \times 2+0,662 \times 3-3,553 \times 4+0,648 \times 5-3,137 \times 6+3,983$

X7 - 0,044 X2X3 + 0,318 X2X4 - 0,052 X2X5 + 0,318 X2X6 - 0,285 X2X7+e

Dari persamaan diatas diketahui bahwa konflik pemakai memiliki nilai positif 1,893; dukungan atasan memiliki pengaruh positif 0,662 ; komunikasi pemakai pengambang memiliki nilai 3,553; kompleksitas tugas memiliki nilai positif 0,648; kompleksitas sistem memiliki nilai negative 3,137; pengalaman pemakai memiliki nilai positif3,983. Untuk konflik pemakai dengan dukungan atasan memiliki nilai negative 0,044; konflik pemakai dengan komunikasi pemakai pengembang memiliki positif nilai 0,318 ; konflik pemakai dengan kompleksitas tugas memiliki nilai negative 0,052; konflik pemakai dengan kompleksitas sistem memiliki nilai positif 0,318 ; konflik pemakai dengan pengalaman pemakai memiliki nilai negative 0,285 . Nilai $(\beta)$ dari masing - masing variabel independent dan pemoderasi $\neq 0$, artinya bahwa masing - masing variabel independent dan pemoderasi dalam model regresi saling berhubungan dan berpengaruh terhadapa variabel dependent.

Adjusted $\mathrm{R}$ square ( $\mathrm{R}$ yang disesuaikan) digunakan untuk mengukur seberapa jauh kemampuan model dalam menerangkan variabel - variabel akuntansi yang diuji meliputi dukungan atasan, komunikasi pemakai pengembang, kompleksitas tugas, kompleksitas sistem, pengalaman pemakai mempunyai kemampuan menjelaskan variasi dari kualitas sistem informasi akuntansi sebesar 0,448 atau $44,8 \%$ sementara sisanya $(100 \%-44,8 \%=55,2 \%)$ dipengaruhi oleh faktor - faktor lain. Hasil ini menunjukkan bahwa variabel independent yang digunakan mempunyai hubungan pola yang cukup kuat dengan kualitas sistem informasi akuntansi.

\section{Uji Hipotesa}

\section{H1: Pengaruh Pemakai Berpengaruh Positif terhadap Kualitas Sistem Informasi Akuntansi}

Pengujian ini menggunakan dua cara yaitu dengan melakukan perbandingan antara nilai $\mathrm{t}$ berdasarkan tabel statistic dengan nilai berdasarkan hasil hitung dengan uji statistic, selain itu dengan melihat nilai signifikasi apabila berada dibawah 0,05 (sig < 0,05) maka H0 ditolak dan sebaliknya berada diatas 0,005 (sig > 0,05) H0 tidak dapat ditolak. Dari uji signifikansi simultan (uji statistic F) sebesar 9,124 dan sig. 0,000. Karena probabilitas jauh lebih kecil dari 0,05; maka model regresi ini dapat digunakan untuk memprediksi kualitas sistem informasi akuntansi atau dapat dikatakan bahwa pengaruh pemakai berpengaruh terhadap kualitas sistem informasi akuntansi. Pengujian diperoleh hasil bahwa koefisien determinasi (R2) variabel pengaruh pemakai (H1) sebesar 0,537; artinya 53,7\% variasi kualitas sistem informasi akuntansi dapat dijelaskan oleh variabel independent pengaruh pemakai. Sedangkan sisanya $46,3 \%$ dijelaskan oleh sebab - sebab lain di luar model.

Pengaruh Pemakai

Dari uji variabel pengaruh pemakai signifikansi parameter individual (uji t Statistik) dengan nilai $t=3,704$ dengan probabilitas signifikan $p=0,003$ $(<0,05)$. Berdasar analisis tersebut maka diperoleh sebuah kesimpulan bahwa pengaruh pemakai positif mempengaruhi kualitas sistem informasi akuntansi dengan kata lain hipotesis pertama $(\mathrm{H} 1)$ diterima dan hipotesis nol 
(H0) ditolak, sehingga didapatkan bahwa semakin tinggi pengaruh pemakai dalam kualitas sistem informasi akuntansi, maka semakin tinggi pula kualitas sistem informasi akuntansi. Dengan demikian maka hasil analisis regresi dapat mendukung hipotesa 1 yang menyatakan bahwa pengaruh pemakai berpengaruh positif terhadap kualitas sistem informasi akuntansi.

\section{H2: Konflik Pemakai Berpengaruh negative terhadap Kualitas Sistem Informasi Akuntansi.}

Pengujian ini menggunakan dua cara yaitu dengan melakukan perbandingan antara nilai $t$ berdasarkan tabel statistic dengan nilai berdasarkan hasil hitung dengan uji statistic, selain itu dengan melihat nilai signifikasi apabila berada dibawah 0,05 (sig < 0,05) maka H0 ditolak dan sebaliknya berada diatas 0,005 (sig > 0,05) H0 tidak dapat ditolak. Dari uji signifikansi simultan (uji statistic F) sebesar 6,683 dan sig. 0,000. Karena probabilitas jauh lebih kecil dari 0,05; maka model regresi ini dapat digunakan untuk memprediksi kualitas sistem informasi akuntansi atau dapat dikatakan bahwa konflik pemakai berpengaruh negatif terhadap kualitas sistem informasi akuntansi. Pengujian diperoleh hasil bahwa koefisien determinasi (R2) variabel pengaruh pemakai (H1) sebesar 0,448; artinya 44,8 \% variasi kualitas sistem informasi akuntansi dapat dijelaskan oleh variabel independent pengaruh pemakai. Sedangkan sisanya 55,2\% dijelaskan oleh sebab - sebab lain di luar model.

Dari uji variabel konflik pemakai signifikansi parameter individual (uji t Statistik) dengan nilai $t=0,364$ dengan probabilitas signifikan $p=0,717(>0,05$ ). Berdasar analisis tersebut maka diperoleh sebuah kesimpulan bahwa konflik pemakai tidak mempengaruhi kualitas sistem informasi akuntansi dengan kata lain hipotesis pertama (H2) ditolak dan hipotesis nol (H0) diterima, sehingga didapatkan bahwa semakin rendahnya konflik pemakai dalam kualitas sistem informasi akuntansi, maka tidak mempengaruhi semakin tingginya kualitas sistem informasi akuntansi. Dengan demikian maka hasil analisis regresi tidak dapat mendukung hipotesa 2 yang menyatakan bahwa konflik pemakai berpengaruh negatif terhadap kualitas sistem informasi akuntansi.

\section{H3: Dukungan Atasan memperkuat Hubungan Positif antara Pengaruh Pemakai dan}

Kualitas Sistem Informasi Akuntansi.

Dari koefisien detreminasi nilai Adjusted R square (R2) output uji hipotesis 3 menghasilkan besarnya $\mathrm{R} 2=0,537$ hal ini berarti 53,7\% variasi kualitas sistem informasi akuntansi yang dapat dijelaskan oleh variasi variabel independent pengaruh pemakai, dukungan atasan dan moderat 1 (interaksi antara variable pengaruh pemakai dan dukungan atasan). Selebihnya 46,3\% dijelaskan oleh sebab - sebab lain diluar model. Dari Uji signifikasi simultan (uji statistic F), Dari uji signifikansi simultan (uji statistic F) sebesar 9,124 dan sig. 0,000 $(<0,05)$, menunjukkan probabilitas signifikasi lebih kecil dari 0,05, maka model regresi dapat digunakan untuk memprediksi kualitas sistem informasi akuntansi atau dapat dikatakan bahwa pengaruh pemakai, dukungan atasan dan moderat 1 secara bersama - sama berpengaruh terhadap kualitas sistem informasi akuntansi. Dari uji signifikansi parameter individual (uji t Statistik) variabel pengaruh pemakai memberikan nilai koefisien sebesar 3,704 dengan tingkat signifikansi

\section{K. Retno \\ Setiorini}

100

JURNAL EKONOMI SYARIAH INDONESIA, Volume V, No.1 Juni 2015 
$0,003(<0,05)$. Variabel dukungan atasan memberikan nilai koefisien parameter sebesar 2,097 dengan tingkat signifikansi 0,000 $(<0,05)$. Variabel moderat 1 memberikan nilai koefisien parameter sebesar $-0,35$ dengan tingkat signifikansi sebesar 0,000 $(<0,05)$. Maka hasil analisis regresi tidak signifikan dan tidak dapat mendukung hipotesa 3 yang menyatakan bahwa Dukungan Atasan memperkuat Hubungan Positif antara Pengaruh Pemakai dan Kualitas Sistem Informasi Akuntansi. sehingga dapat disimpulkan bahwa variabel dukungan atasan merupakan variabel moderating yang memperlemah hubungan variabel pengaruh pemakai dan kualitas sistem informasi akuntansi.

\section{H4: Komunikasi Pemakai - Pengembang memperkuat Hubungan Positif antara Pengaruh}

Pemakai dan Kualitas Sistem Informasi Akuntansi.

Dari koefisien detreminasi nilai Adjusted R square (R2) output uji hipotesis 4 menghasilkan besarnya $\mathrm{R} 2=0,537$ hal ini berarti $53,7 \%$ variasi kualitas system informasi akuntansi yang dapat dijelaskan oleh variasi variabel independent pengaruh pemakai, komunikasi pemakai pengembang dan moderat 2 (interaksi antara variable pengaruh pemakai dan komunikasi pemakai pengembang). Selebihnya 46,3\% dijelaskan oleh sebab - sebab lain diluar model. Dari Uji signifikasi simultan (uji statistic F), menghasilkan nilai F hitung sebesar 9,124 dengan tingkat signifikasi 0,000 $(<0,05)$, menunjukkan probabilitas signifikasi lebih kecil dari 0,05, maka model regresi dapat digunakan untuk memprediksi kualitas sistem informasi akuntansi atau dapat dikatakan bahwa pengaruh pemakai, komunikasi pemakai pengembang dan moderat 2 secara bersama - sama berpengaruh terhadap kualitas sistem informasi akuntansi. Dari uji signifikansi parameter individual (uji t Statistik) variable pengaruh pemakai memberikan nilai koefisien sebesar 3,704 dengan tingkat signifikansi 0,003 $(<0,05)$. Variabel komunikasi pemakai pengembang memberikan nilai koefisien parameter sebesar $-6,586$ dengan tingkat signifikansi $0,008(<0,05)$. Variabel moderat 2 memberikan nilai koefisien parameter sebesar 0,136 dengan tingkat signifikansi sebesar 0,002 $(<0,05)$. Maka hasil analisis regresi tidak mendukung hipotesis 4 yang menyatakan bahwa Komunikasi Pemakai - Pengembang memperkuat Hubungan Positif antara Pengaruh Pemakai dan Kualitas Sistem Informasi Akuntansi, sehingga dapat disimpulkan bahwa variabel komunikasi pemakai pengembang bisa menjadi variabel moderating yang memperlemah hubungan variabel pengaruh pemakai dan kualitas sistem informasi akuntansi.

\section{H5: Kompleksitas Tugas memperkuat Hubungan Positif antara Pengaruh Pemakai dan Kualitas Sistem Informasi Akuntansi.}

Dari koefisien detreminasi nilai Adjusted R square (R2) output uji hipotesis 5 menghasilkan besarnya $\mathrm{R} 2=0,537$ hal ini berarti 53,7 \% variasi kualitas sistem informasi akuntansi yang dapat dijelaskan oleh variasi variabel independent pengaruh pemakai, kompleksitas tugas dan moderat 3 (interaksi antara variabel pengaruh pemakai dan kompleksitas tugas). Selebihnya 46,3\%

Pengaruh Pemakai dijelaskan oleh sebab - sebab lain diluar model. Dari Uji signifikasi simultan (uji statistic $F$ ), menghasilkan nilai $F$ hitung sebesar 9,124 dengan tingkat signifikasi 0,000 (<0,05), menunjukkan probabilitas signifikasi lebih kecil dari 0,05, maka model regresi dapat digunakan memprediksi kualitas sistem informasi akuntansi atau dapat dikatakan bahwa pengaruh pemakai, kompleksitas tugas

JURNAL EKONOMI SYARIAH INDONESIA, Volume V, No.1 Juni 2015 
dan moderat 3 secara bersama - sama berpengaruh terhadap kualitas sistem informasi akuntansi. Dari uji signifikansi parameter individual (uji t Statistik) variable pengaruh pemakai memberikan nilai koefisien sebesar 3,704 dengan tingkat signifikansi 0,003 $(<0,05)$. Variabel kompleksitas tugas memberikan nilai koefisien parameter sebesar 2,823 dengan tingkat signifikansi 0,224 ( $>0,05$ ). Variabel moderat 3 memberikan nilai koefisien parameter sebesar $-0,054$ dengan tingkat signifikansi sebesar 0,199 (>0,05). Maka hasil analisa regresi tidak mendukung hipotesis 5 yang menyatakan bahwa Kompleksitas Tugas memperkuat Hubungan Positif antara Pengaruh Pemakai dan Kualitas Sistem Informasi Akuntansi. Variabel moderat yang merupakan interaksi antara pengaruh pemakai dan kompleksitas tugas ternyata tidak signifikan.

\section{H6: Kompleksitas Sistem memperkuat Hubungan Positif antara Pengaruh Pemakai dan Kualitas Sistem Informasi Akuntansi.}

Dari koefisien detreminasi nilai Adjusted R square (R2) output uji hipotesis 6 menghasilkan besarnya $\mathrm{R} 2=0,537$ hal ini berarti 53,7 \% variasi kualitas sistem informasi akuntansi yang dapat dijelaskan oleh variasi variabel independent pengaruh pemakai, kompleksitas sistem dan moderat 4 (interaksi antara variable pengaruh pemakai dan kompleksitas sistem). Selebihnya 46,3\% dijelaskan oleh sebab - sebab lain diluar model. Dari Uji signifikasi simultan (uji statistic F), menghasilkan nilai F hitung sebesar 9,124 dengan tingkat signifikasi $0,000(<0,05)$, menunjukkan probabilitas signifikasi lebih kecil dari 0,05, maka model regresi dapat digunakan untuk memprediksi kualitas sistem informasi akuntansi atau dapat dikatakan bahwa pengaruh pemakai, kompleksitas sistem dan moderat 6 secara bersama - sama berpengaruh terhadap kualitas sistem informasi akuntansi.

Dari uji signifikansi parameter individual (uji t Statistik) variable pengaruh pemakai memberikan nilai koefisien sebesar 3,074 dengan tingkat signifikansi 0,003 $(<0,05)$. Variabel kompleksitas sistem memberikan nilai koefisien parameter sebesar -3,141 dengan tingkat signifikansi 0,202 (>0,05). Variabel moderat memberikan nilai koefisien parameter sebesar 0,070 dengan tingkat signifikansi sebesar 0,130 $(>0,05)$. Variabel moderat yang merupakan interaksi antara pengaruh pemakai dan kompleksitas sistem ternyata tidak signifikan dan variable kompleksitas system tidak bisa menjadi variable moderating.

\section{H7: Pengalaman pemakai memperkuat Hubungan Positif antara Pengaruh Pemakai dan Kualitas Sistem Informasi Akuntansi.}

Dari koefisien detreminasi nilai Adjusted R square (R2) output uji hipotesis 7 menghasilkan besarnya R2 $=0,537$ hal ini berarti 53,7 \% variasi kualitas system informasi akuntansi yang dapat dijelaskan oleh variasi variable independent pengaruh pemakai, pengalaman pemakai dan moderat 5 (interaksi antara variable pengaruh pemakai dan pengalaman pemakai). Selebihnya 46,3\% dijelaskan oleh sebab - sebab lain diluar model. Dari Uji signifikasi simultan (uji statistic F), menghasilkan nilai F hitung sebesar 9,124 dengan tingkat signifikasi 0,000 $(<0,05)$, menunjukkan probabilitas signifikasi lebih kecil dari 0,05, maka model regresi dapat digunakan untuk memprediksi kualitas system informasi akuntansi atau dapat dikatakan bahwa pengaruh pemakai, pengalaman pemakai dan moderat 5 secara bersama - sama berpengaruh terhadap kualitas system informasi akuntansi.

K. Retno

Setiorini

102

JURNAL EKONOMI SYARIAH INDONESIA, Volume V, No.1 Juni 2015 
Dari uji signifikansi parameter individual (uji t Statistik) variable pengaruh pemakai memberikan nilai koefisien sebesar 3,704 dengan tingkat signifikansi 0,003 $(<0,05)$. Variabel pengalaman pemakai memberikan nilai koefisien parameter sebesar 6,964 dengan tingkat signifikansi 0,000 $(<0,05)$. Variabel moderat memberikan nilai koefisien parameter sebesar -0,123 dengan tingkat signifikansi sebesar 0,000 $(<0,05)$. Maka hasil analisis regresi tidak signifikan dan tidak mendukung hipotesa 7 yang menyatakan pengalaman pemakai memperkuat hubungan positif antara pengaruh pemakai dan kualitas sistem informasi akuntansi. Variabel moderat yang merupakan interaksi antara pengaruh pemakai dan pengalaman pemakai ternyata memperlemah hubungan variabel pengaruh pemakai dan kualitas sistem informasi akuntansi dan variabel pengalaman pemakai bisa menjadi variabel moderating.

\section{H8: Dukungan Atasan memperkuat Hubungan negative antara Konflik Pemakai dan Kualitas Sistem Informasi Akuntansi.}

Dari koefisien detreminasi nilai Adjusted R square (R2) output uji hipotesis 8 menghasilkan besarnya $\mathrm{R} 2=0,448$ hal ini berarti $44,8 \%$ variasi kualitas system informasi akuntansi yang dapat dijelaskan oleh variasi variable independent konflik pemakai, dukungan atasan dan moderat (interaksi antara variable konflik pemakai dan ukungan atasan). Selebihnya 55,2 \% dijelaskan oleh sebab - sebab lain diluar model. Dari Uji signifikasi simultan (uji statistic F), menghasilkan nilai F hitung sebesar 6,684 dengan tingkat signifikasi 0,000 $(<0,05)$, menunjukkan probabilitas signifikasi lebih kecil dari 0,05, maka model regresi dapat digunakan untuk memprediksi kualitas system informasi akuntansi atau dapat dikatakan bahwa konflik pemakai, dukungan atasan dan moderat 6 secara bersama - sama berpengaruh terhadap kualitas system informasi akuntansi. Dari uji signifikansi parameter individual (uji t Statistik) variable konflik pemakai memberikan nilai koefisien sebesar 1,895 dengan tingkat signifikansi 0,717 $(>0,05)$. Variabel dukungan atasan memberikan nilai koefisien parameter sebesar 0,662 dengan tingkat signifikansi 0,717 (> $0,05)$. Variabel moderat 6 memberikan nilai koefisien parameter sebesar $-0,044$ dengan tingkat signifikansi sebesar 0,720 (>0,05). Maka hasil analisa regresi tidak mendukung hipotesa 8 yang menyatakan bahwa Dukungan Atasan memperkuat Hubungan negative antara Konflik Pemakai dan Kualitas Sistem Informasi Akuntansi. Variabel moderat 6 yang merupakan interaksi antara konflik pemakai dan dukungan atasan ternyata tidak signifikan dan variable dukungan atasan tidak bisa menjadi variable moderating.

\section{H9: Komunikasi Pemakai - Pengembang memperkuat Hubungan negative antara Konflik Pemakai dan Kualitas Sistem Informasi Akuntansi.}

Dari koefisien detreminasi nilai Adjusted R square (R2) output uji hipotesis 9 menghasilkan besarnya R2 $=0,448$ hal ini berarti 44,8 \% variasi kualitas system informasi akuntansi yang dapat dijelaskan oleh variasi variable independent konflik pemakai, komunikasi pemakai pengembang dan moderat 7 (interaksi antara variable konflik pemakai dan komunikasi pemakai pengembang). Selebihnya 55,2 \% dijelaskan oleh sebab - sebab lain

Pengaruh Pemakai diluar model. Dari Uji signifikasi simultan (uji statistic F), menghasilkan nilai F hitung sebesar 6,684 dengan tingkat signifikasi $0,000(<0,05)$, menunjukkan probabilitas signifikasi lebih kecil dari 0,05, maka model regresi dapat digunakan untuk memprediksi kualitas system informasi akuntansi atau 
dapat dikatakan bahwa konflik pemakai, komunikasi pemakai pengembang dan moderat 7 secara bersama - sama berpengaruh terhadap kualitas system informasi akuntansi. Dari uji signifikansi parameter individual (uji t Statistik) variable konflik pemakai memberikan nilai koefisien sebesar 1,895 dengan tingkat signifikansi 0,717 $(>0,05)$. Variabel komunikasi pemakai pengembang memberikan nilai koefisien parameter sebesar -3,533 dengan tingkat signifikansi 0,165 ( >0,05). Variabel moderat 7 memberikan nilai koefisien parameter sebesar 0,318 dengan tingkat signifikansi sebesar 0,085 ( > 0,05). Maka hasil analisa regresi tidak mendukung hipotesa 9 yang menyatakan bahwa Komunikasi Pemakai - Pengembang memperkuat Hubungan negative antara Konflik Pemakai dan Kualitas Sistem Informasi Akuntansi. Variabel moderat yang merupakan interaksi antara konflik pemakai dan komunikasi pemakai pengembang ternyata tidak signifikan dan variable komunikasi pemakai pengembang tidak bisa menjadi variable moderating.

H10: Kompleksitas Tugas memperkuat Hubungan negative antara Konflik Pemakai dan Kualitas Sistem Informasi Akuntansi.

Dari koefisien detreminasi nilai Adjusted R square (R2) output uji hipotesis 10 menghasilkan besarnya $\mathrm{R} 2=0,448$ hal ini berarti $44,8 \%$ variasi kualitas system informasi akuntansi yang dapat dijelaskan oleh variasi variable independent konflik pemakai, kompleksitas tugas dan moderat 8 (interaksi antara variable konflik pemakai dan kompleksitas tugas). Selebihnya 55,2 \% dijelaskan oleh sebab - sebab lain diluar model. Dari Uji signifikasi simultan (uji statistic F), menghasilkan nilai $\mathrm{F}$ hitung sebesar 6,684 dengan tingkat signifikasi $0,000(<0,05)$, menunjukkan probabilitas signifikasi lebih kecil dari 0,05, maka model regresi dapat digunakan untuk memprediksi kualitas system informasi akuntansi atau dapat dikatakan bahwa konflik pemakai, kompleksitas tugas dan moderat 8 secara bersama - sama berpengaruh terhadap kualitas system informasi akuntansi.

Dari uji signifikansi parameter individual (uji t Statistik) variable konflik pemakai memberikan nilai koefisien sebesar 1,895 dengan tingkat signifikansi 0,717 ( > 0,05). Variabel kompleksitas tugas memberikan nilai koefisien parameter sebesar 0,648 dengan tingkat signifikansi 0,709 (>0,05). Variabel moderat 8 memberikan nilai koefisien parameter sebesar $-0,052$ dengan tingkat signifikansi sebesar 0,696 $(>0,05)$. Variabel moderat 8 yang merupakan interaksi antara konflik pemakai dan kompleksitas tugas ternyata tidak signifikan dan variable kompleksitas tugas tidak bisa menjadi variable moderating.

\section{H11: Kompleksitas Sistem memperkuat Hubungan negative antara Konflik Pemakai dan Kualitas Sistem Informasi Akuntansi.}

Dari koefisien detreminasi nilai Adjusted R square (R2) output uji hipotesis 11 menghasilkan besarnya $\mathrm{R} 2=0,448$ hal ini berarti 44,8\% variasi kualitas system informasi akuntansi yang dapat dijelaskan oleh variasi variable independent konflik pemakai, kompleksitas sistem dan moderat 9 (interaksi antara variable konflik pemakai dan kompleksitas sistem). Selebihnya 55,2 \% dijelaskan oleh sebab - sebab lain diluar model. Dari Uji signifikasi simultan (uji statistic F), menghasilkan nilai $F$ hitung sebesar 6,684 dengan tingkat signifikasi 0,000 $(<0,05)$, menunjukkan probabilitas signifikasi lebih kecil dari 0,05, maka model regresi dapat digunakan untuk memprediksi kualitas

K. Retno

Setiorini

104

JURNAL EKONOMI SYARIAH INDONESIA, Volume V, No.1 Juni 2015 
system informasi akuntansi atau dapat dikatakan bahwa konflik pemakai, kompleksitas system dan moderat 9 secara bersama - sama berpengaruh terhadap kualitas system informasi akuntansi. Dari uji signifikansi parameter individual (uji t Statistik) variable konflik pemakai memberikan nilai koefisien sebesar 1,895dengan tingkat signifikansi 0,717 (>0,05). Variabel kompleksitas sistem memberikan nilai koefisien parameter sebesar -3,137 dengan tingkat signifikansi 0,255 ( >0,05). Variabel moderat 9 memberikan nilai koefisien parameter sebesar 0,318 dengan tingkat signifikansi sebesar 0,141 $(>0,05)$. Maka hasil analisis regresi tidak mendukung hipotesa 11 yang menyatakan bahwa kompleksitas system memperkuat hubungan negative antara konflik pemakai dan kualitas system informasi akuntansi. Variabel moderat 9 yang merupakan interaksi antara konflik pemakai dan kompleksitas sistem ternyata tidak signifikan dan variable kompleksitas system tidak bisa menjadi variable moderating.

\section{H12: Pengalaman Pemakai memperkuat Hubungan negative antara Konflik Pemakai dan Kualitas Sistem Informasi Akuntansi.}

Dari koefisien detreminasi nilai Adjusted R square (R2) output uji hipotesis 8 menghasilkan besarnya $\mathrm{R} 2=0,448$ hal ini berarti $44,8 \%$ variasi kualitas system informasi akuntansi yang dapat dijelaskan oleh variasi variable independent konflik pemakai, pengalaman pemakai dan moderat 10 (interaksi antara variable konflik pemakai dan pengalaman pemakai). Selebihnya 55,2 \% dijelaskan oleh sebab - sebab lain diluar model. Dari Uji signifikasi simultan (uji statistic F), menghasilkan nilai $\mathrm{F}$ hitung sebesar 6,684 dengan tingkat signifikasi 0,000 $(<0,05)$, menunjukkan probabilitas signifikasi lebih kecil dari 0,05, maka model regresi dapat digunakan untuk memprediksi kualitas system informasi akuntansi atau dapat dikatakan bahwa konflik pemakai, pengalaman pemakai dan moderat 10 secara bersama - sama berpengaruh terhadap kualitas system informasi akuntansi. Dari uji signifikansi parameter individual (uji t Statistik) variable konflik pemakai memberikan nilai koefisien sebesar 1,895 dengan tingkat signifikansi 0,717 (>0,05). Variabel pengalaman pemakai memberikan nilai koefisien parameter sebesar 3,983 dengan tingkat signifikansi 0,000 $(<0,05)$. Variabel moderat 10 memberikan nilai koefisien parameter sebesar $-0,285$ dengan tingkat signifikansi sebesar 0,000 $(<0,05)$. Maka hasil analisis regresi tidak signifikan dan tidak mendukung hipotesa 12 yang menyatakan bahwa Pengalaman Pemakai memperkuat Hubungan negative antara Konflik Pemakai dan Kualitas Sistem Informasi Akuntansi. Variabel moderat 10 yang merupakan interaksi antara konflik pemakai dan pengalaman pemakai ternyata memperlemah hubungan antara konflik pemakai dan kualitas system informasi akuntansi.

\section{KESIMPULAN}

Faktor yang melatarbelakangi dilakukan penelitian ini untuk mengetahui kualitas sistem informasi akuntansi di SKPD Pekanbaru agar di masa yang akan datang lebih ditingkatkan lagi kualitas sistem informasi akuntansi, dimana akan mendorong peningkatan pelayanan pada masyarakat. Berdasarkan hasil

Pengaruh pengujian yang dilakukan maka dapat disimpulkan:

Pemakai

105

JURNAL EKONOMI SYARIAH INDONESIA, Volume V, No.1 Juni 2015 
Pengaruh pemakai berpengaruh positif terhadap kualitas sistem informasi akuntansi.

Berdasarkan hasil analisa data, diketahui bahwa pengaruh pemakai berpengaruh positif terhadap kualits system informasi akuntansi dengan pengaruhnya tidak terlalu besar yang ditunjukkan dengan koefisien determinasi sebesar 0,537; namun pengaruh pemakai dapat menjadi bahan pertimbangan untuk mendukung tercapainya kualitas system informasi akuntansi.

\section{Konflik pemakai tidak berpengaruh negatif terhadap kualitas system informasi akuntansi}

Berdasarkan hasil analisa data, diketahui bahwa konflik pemakai tidak berpengaruh negative terhadap kualitas sistem informasi akuntansi. Sehingga dalam penelitian ini dihasilkan bahwa model regresi konfik pemakai dapat dipakai untuk melakukan penelitiaan terhadap kualitas sistem informasi akuntansi, dengan koefisien determinasi sebesar 44,8\% dimana $55,2 \%$ dapat dijelaskan dengan faktor - faktor yang lain, namun dari hasil analisa data bahwa konflik pemakai tidak berpengaruh negative terhadap kualitas sistem informasi akuntansi, hal ini menunjukkan bahwa kualiats sistem informasi akuntansi tidak dipengaruhi oleh konflik pemakai.

\section{Pengaruh pemakai dimoderasi dukungan atasan tidak berpengaruh positif terhadap kualitas sistem informasi akuntansi.}

Dari hasil analisa data tidak signifikan dan tidak mendukung interaksi antara pengaruh pemakai dengan dukungan atasan dapat mempengaruhi kualitas sistem informasi akuntansi, walaupun variabel moderating yang memperlemah hubungan pengaruh pemakai dan kualitas sistem informasi akuntansi yang memiliki nilai koefisien determinasi sebesar 0,537\% dan 46,3\% dijelaskan diluar faktor - faktor lainnya.

\section{Pengaruh pemakai dimoderasi komunikasi pemakai pengembang tidak} berpengaruh positif terhadap kualitas sistem informasi akuntansi.

Hasil analisa data diketahui bahwa dapat dikatakan bahwa variabel komunikasi pemakai pengembang tidak memperkuat hubungan antara pengaruh pemakai dengan kualitas sistem informasi akuntansi. Walaupun variabel komunikasi pemakai pengembang bisa menjadi variabel pemoderasi yang memperlemah hubungan antara pengaruh pemakai dan kualitas sistem informasi akuntansi. Dengan demikian komunikasi pemakai pengembang tidak mempengaruhi kualitas sistem informasi akuntansi, namun model regresi penelitian komunikasi pemakai pengembang dapat mempengaruhi kualitas sistem informasi akuntansi dengan koefisien determinasi 0,537 atau $53,7 \%$ dan $46,3 \%$ dijelaskan diluar faktor - faktor lainnya.

\section{Pengaruh pemakai dimoderasi kompleksitas tugas tidak berpengaruh positif} terhadap kualitas sistem informasi akuntansi.

Berdasarkan analisa data diketahui bahwa kompleksitas tugas tidak memoderasi hubungan berpengaruh pemakai terhadap kualitas sistem informasi akutansi, dapat dikatakan bahwa kompleksitas tugas tidak signifikan hubungan antara pengaruh pemakai dengan kualitas sistem

K. Retno

Setiorini

106

JURNAL EKONOMI SYARIAH INDONESIA, Volume V, No.1 Juni 2015 
informasi akuntansi. Pada penelitian ini diketahui koefisien detreminasi sebesar 0,537 atau 53,7\% dan 46,3\% dijelaskan diluar faktor - faktor, namun model regresi ini dapat digunakan sebagi penelitian terhadap kualitas sistem informasi akuntansi. Sehingga pada kompleksitas tugas yang tinggi tanpa didukung dengan kualitas sistem informasi akuntansi yang tinggi maka akan menimbulkan sebuah pemikiran bahwa individu akan merasa kesulitan dalam menjalankan suatu tugas yang telah terstruktur dan berpola, namun pada sebagian individu yang lain akan dapat dilakukan dengan mudah dalam mengerjakannya dan menciptakan kualitas sistem informasi akuntansi.

\section{Pengaruh pemakai dimoderasi kompleksitas system tidak berpengaruh positif terhadap kualitas sistem informasi akuntansi.}

Dari hasil analisa data dapat disimpulkan bahwa variabel moderat yang merupakan interaksi antara pengaruh pemakai dan kompleksitas sistem ternyata tidak signifikan dan penelitian ini memiliki koefisien determinasi 0,537 atau 53,7\% dan 46,3\% dijelaskan diluar faktor - faktor lainnya.

Pengaruh pemakai dimoderasi pengalaman pemakai tidak berpengaruh positif terhadap kualitas sistem informasi akuntansi.

Maka hasil analisis regresi tidak signifikan dan tidak mendukung hipotesa 7 yang menyatakan pengalaman pemakai memperkuat hubungan positif antara pengaruh pemakai dan kualitas sistem informasi akuntansi. Variabel moderat yang merupakan interaksi antara pengaruh pemakai dan pengalaman pemakai ternyata memperlemah hubungan variabel pengaruh pemakai dan kualitas sistem informasi akuntansi. Dengan koefisian determinasi sebesar 0,537 atau $53,7 \%$ dan $44,6 \%$ dijelaskan diluar faktor - faktor, namun model regresi ini dapat digunakan untuk menguji penelitian kualitas sistem informasi akuntansi.

Konflik pemakai dimoderasi dukungan atasan tidak berpengaruh negative terhadap kualitas sistem informasi akuntansi.

Maka hasil analisa regresi tidak mendukung hipotesa 8 yang menyatakan bahwa Dukungan Atasan memperkuat Hubungan negative antara Konflik Pemakai dan Kualitas Sistem Informasi Akuntansi. Variabel moderat 6 yang merupakan interaksi antara konflik pemakai dan dukungan atasan ternyata tidak signifikan dan variabel dukungan atasan tidak bisa menjadi variable moderating. Dengan koefisien determinasi 0,448\% dan 55,2\% dijelaskan diluar faktor - faktor.

Konflik pemakai dimoderasi komunikasi pemakai pengembang tidak berpengaruh negative terhadap kualitas sistem informasi akuntansi.

Hasil analisa diketahui penelitian komunikasi pemakai pengembang tidak berpengaruh negative hubungan antara konflik pemakai terhadap kualitas sistem informasi akuntansi. Sehingga komunikasi pemakai pengembang tidak memperkuat atau memperlemah hubungan antara konflik pemakai

Pengaruh dengan kualitas sistem informasi akuntansi. Diketahui koefisien determinasi Pemakai sebesar $0,448 \%$ atau $44,8 \%$ dan $55,2 \%$ dijelaskan diluar faktor - faktor, namun model regresi ini dapat digunakan untuk penelitian terhadap kualitas sistem informasi akuntansi. 


\section{Konflik pemakai dimoderasi kompleksitas tugas tidak berpengaruh negative terhadap kualitas sistem informasi akuntansi.}

Hasil analisa diketahui penelitian kompleksitas tugas tidak berpengaruh negative hubungan antara konflik pemakai terhadap kualitas sistem informasi akuntansi. Sehingga komunikasi pemakai pengembang tidak memperkuat atau memperlemah hubungan antara konflik pemakai dengan kualitas sistem informasi akuntansi. Diketahui koefisien determinasi sebesar 0,448\% atau $44,8 \%$ dan 55,2\% dijelaskan diluar faktor - faktor, namun model regresi ini dapat digunakan untuk penelitian terhadap kualitas sistem informas akuntansi. Walaupun dalam penelitian ini kompleksitas tugas tidak mempengaruhi semakin rendah konflik pemakai terhadap semakin tinggi kualitas sistem informasi akuntansi. Sehingga kompleksitas tugas yang tinggi tanpa didukung dengan konflik pemakai maka tidak akan memberikan pengaruh terhadap kualitas sistem informasi akuntansi. Dalam hal ini interaksi kompleksitas tugas dengan konflik pemakai sangat rendah sehingga tidak mempengaruhi hubungan antara konflik terhadap kualitas sistem informasi akuntansi.

\section{Konflik pemakai dimoderasi kompleksitas system tidak berpengaruh negative terhadap kualitas sistem informasi akuntansi.}

Hasil analisa diketahui penelitian kompleksitas sistem tidak berpengaruh negative hubungan antara konflik pemakai terhadap kualitas system informasi akuntansi. Sehingga komunikasi pemakai pengembang tidak memperkuat atau memperlemah hubungan antara konflik pemakai dengan kualitas sistem informasi akuntansi. Diketahui koefisien determinasi sebesar 0,448 atau 44,8\% dan 55,2\% dijelaskan diluar faktor - faktor, namun model regresi ini dapat digunakan untuk penelitian terhadap kualitas sistem informas akuntansi. Sehingga dalam penelitian ini kompleksitas sistem tidak mempengaruhi semakin rendah konflik pemakai terhadap semakin tinggi kualitas sistem informasi akuntansi.

Konflik pemakai dimoderasi pengalaman pemakai berpengaruh negative terhadap kualitas system informasi akuntansi.

Maka hasil analisis regresi tidak signifikan dan tidak mendukung hipotesa 12 yang menyatakan bahwa Pengalaman Pemakai memperkuat Hubungan negative antara Konflik Pemakai dan Kualitas Sistem Informasi Akuntansi. Variabel moderat 10 yang merupakan interaksi antara konflik pemakai dan pengalaman pemakai ternyata memperlemah hubungan antara konflik pemakai dan kualitas system informasi akuntansi. Diketahui koefisien determinasi sebesar 0,448 atau $44,8 \%$ dan $55,2 \%$ dijelaskan diluar factor factor, namun model regresi ini dapat digunakan untuk penelitian terhadap kualitas system informas akuntansi.

\section{DAFTAR PUSTAKA}

ANSI/ ASQC. 1978. Quality Systems terminology. Milwaukee, Wis.: American Society for Quality Control.

Azhar Susanto (2009) Sistem informasi manajemen. Bandung: Lingga Jaya.

Azhar Susanto (2008) Sistem Informasi Akuntansi Konsep dan Pengembangan berbasis computer. Bandung: Lingga jaya.

K. Retno

Setiorini

108

JURNAL EKONOMI SYARIAH INDONESIA, Volume V, No.1 Juni 2015 
Amrul, Sadat dan Syar'ie, Ahyadi. 2005. Analisis Beberapa Faktor yang Berpengaruh Terhadap proses Pengembangan Kualitas Sistem. Simposium nasional Akuntansi VIII. Solo.

Astuti Negerahmawati (2013). Pengaruh Partisipasi Pemakai Sistem Informasi, kemampuan Pemakai Sistem Informasi, Ukuran Organisasi Terhadap Kinerja Sistem Informasi AKuntansi dengan Kompleksitas Tugas Sebagai Variabel Moderating (studi PT. PLN (Persero) Distribusi Jawa Barat dan Banten).

Bodnar, G.H dan William S., Hopwood. 1995. Accounting Information systems. Prentice hall International, $6^{\text {th }}$. Ed.

Bodnar, George H \& Hopwood, William S (2010), Accounting Information System, Tenth Edition, Pearson education inc. upper saddle river, New Jersey.

Choe, Jong-Min. 1996. The Relationship Among Performance of Accounting Information Systems, influence factors, and Evolution level of Information Systems. Journal of management Information System. Vol 12. No.4. Spring.

Choe, Jong-Min. 1996. The Relationship Among Performance of Accounting Information Systems, Influence Factors, and Evolution Level of Information System. Journal of Managemnet Information System. Vol 12. No. 4. Spring.

Dillworth, J. B. 1988. Production and operations management, $3^{\text {rd }}$ edition. New York: Random House.

Debrabander, D dan G, Their. 1984, Succesful Information System Developmant in Relation to Situasional factors Which Affect Effective Communication Between MIS Users and EDP Spesialist. Management Science. Vol. 30. No. 2. February.

Davis FD.1989. Perceved Usefullness, Perceived ease of use of Information Technology. Managemnet Information System Quartely, 21 (3)

Elfreda Aplonia Lau, 2004. Pengaruh partisipasi Pemakai Terhadap Kepuasan pemakai Dalam Pengembangan Sistem Informasi Dengan Lima Variabel Moderating, Jurnal Riset Akuntansi Indonesia Volume 7. No. 1. Januari.

Edstrom, A. 1977. User Influence and the Success of MIS Project: A Contigency Approach. Human relation. Vol. 30. No.7.

Ginzberg, M.J. 1981. Early Diagnosisi of Implementation Failure: Priomising Result and Unanswered Questions. Management Sciences. Vol. 27. No. 4. April.

Gibson, L James, John M Ivancevich, dan James H Donelly. 2003. Organization: Behavior, Structure and Process. $10^{\text {th }}$ edition. Irwin. Chicago.

Guimaraes, T., D. S. Staples, dan J. D. Mckeen, 2003. Empirically Testing Some main User-Related Factors for System Development Quality. Quality Managemnet Journal 10, no. 4:39-54.

Pengaruh Pemakai

Hwang, M. I., and R. G. Thorn. 1999. The effect of user engagement on system success: A meta analytical integration of research findings. Information \& Management 35, no. 4:229-236. 
Iqbaria,M.,P.Saroj.dan K.B.,Michael. !((\$. Work experience, Job Involvemnet, and Quality Work of Life Among Information System Personnel. MIS Quartely. June.

Kim, E. dan J. Lee. 1986. An Exploratory Contingency Model of user participation and MIS Use. Information \& management. Vol. 11. No.2.

Kim, E. dan J. lee. 1986. An Exploratory Contingency Model of User Participation and MIS Use. Information \& Managemnet. Vol. 11. No. 2.

Lin, W. T., and B. B. M. shao. 2000. The relationship between user participation and system success: A simultaneous contingency approach. Information \& Management 37, no. 6: 283-295.

Mckeen, J. D., T. Guimaraes, and J. C. Wetherbe. 1994. The relationship between user participation and user satisfaction: An investigation of four contingency factors. MIS Quarterly 18, no. 4: 427-451.

Mahmood, M. A, J. M. Burn, L. A. Gemoets, and C. Jacquez. 2000. Variabels affecting information technology end-user satisfaction: A meta-analysis of the empirical literature. International Journal of Human-Computer Studie 52, no. 4: 751-771.

McKeen D.J, G, Tor dan C.W., James. 1994. The relationship of User participation and User satisfaction: An Investigation of Four Contingency Factors. MIS Quarterly. December.

Nugroho Widjajanto. 2001. Sistem Informasi Akuntansi. Erlangga: Jakarta.

Nur Indriantoro, dan Setianingsih. 1998. Pengaruh dukungn Manajemen puncak dan komunikasi pemakai pengembang: terhadap hubungan partisipasi dan kepuasan kerja pemakai dalam pengembangan system informasi: Jurnal Riset Akuntansi Indonesia (JRAI), Volume Juli, Yogyakarta.

2000. Pengaruh Computer Anxiety terhadap keahlian dosen dalam menggunakan computer. Jurnal Akuntansi dan Auditing (JAAI), Volume 4 no. 2 Desember. Fakultas Ekonomi, Universitas Islam Indonesia (UII). Yogyakarta.

Robey, D, dan D.L. farrow. 1982. User Involvement in information System Development: A Conflict Model and Empirical Test. Managemnet Science. January.

Robey, D. 1994. Modeling interpersonal processes during systems development: Further thoughts and suggestions. Information systems research 5, no. 4:439-445.

Robey. D., and D. Farrow. 1982. User involment in information systems development: a conflict model and empirical test. Management Science 26, no.1: 73-85.

Robey, D., D. Farrow, and C. R. Franz. 1989. Group process and conflict in system development. Managemnet Science 35, no. 10:1172-1189.

Romney, Marshall B. \& pal Jhon Steinbart, (2009), Accounting Information System, Eleventh Edition, Prentice Hall.

Sekaran, U, 1994. Research Methods for Business: A skill Building Approach. 3th John Wiley and Sons inc, Second Edition. Singapore.

K. Retno

Setiorini

110

JURNAL EKONOMI SYARIAH INDONESIA, Volume V, No.1 Juni 2015 
Soegiharto, (2001). Influence Factors Affecting The Performance of Accounting Information Systems. Gajah Mada International Journal of Business. May. Vol. 3 No. 2 pp. 177-202.

Tait, P dan I., Vessey. 1988. The Effect of User Involvement on Systems Success: A Contingency Approach. MIS Quarterly. March.

Tri Sulaksono, 2013. Budaya Organisasi dan Ketidakpastian Lingkungan Sevagai Variabel Moderating Dalam Hubungan antara gaya evaluasi atasan terhadap tekanan kerja dan Kepuasan Kerja Bawahan.

Vanlommel, E, dan Debander, B. 1975. The Organization of EDP Activities and Computer Use. Journal of Bussiness

Wilkinson, Joseph W, Michael W Cerullo, vasant raval dan Bernard wong On Wing. 2000. Accounting Information Systems. John Wiley Inc.

Pengaruh

Pemakai

111

JURNAL EKONOMI SYARIAH INDONESIA, Volume V, No.1 Juni 2015 